\author{
Janusz Lemański \\ University of Szczecin \\ ORCID: 000-0002-1512-997x
}

\title{
(Post-)Deuteronomistic Prohibition of Transvestitism (Deut 22:5)? The Question of Its Actual Meaning and Motivations ${ }^{1}$
}

\begin{abstract}
Deut 22:5 marks the single instance of a prohibition of transvestitism in the Bible, and in its whole cultural milieu. The context in which it is situated suggests that it may have been inserted there as an addition, after the Babylonian captivity. That helps to narrow down the range of speculations as to the original Sitz im Leben of the law and enables us to read it most of all within the canonical framework of the entirety of the Pentateuch. Hence, the precept pertains mainly to the principle of division of the human nature into the two sexes (Gen 1-2), the principle of retaining the order of creation (by not mixing kinds; Lev 19:19; Deut 22:9-11), and of keeping the procreational power, referred to here predominantly to masculinity (Gen 5:1-3; cf. Gen 1:28; 9:1.7).
\end{abstract}

Keywords: transvestitism, masculinity, Book of Deuteronomy, sex, gender, procreation

The form of a "typical" female and male attire is determined by 1 the geographical, historical, and social circumstances. It suffices to compare in that regard the "typical" menswear and womenswear in Europe with that in China, or even within Europe, simply taking into consideration the traditional garb of Scotsmen and, say, the ancient garments of Greeks and Romans. The gender character of a given item of clothing is, therefore, defined by the

1 This article is a translation of the article originally published in Polish: Janusz Lemański, "(Post-)deuteronomistyczny zakaz transwestytyzmu (Pwt 22,5)? Pytanie o jego właściwy sens i motywację," Collectanea Theologica 90 (2020) no. 1, 77-104. Translated from Polish by Lingua Lab. 
community, which is in turn influenced by its culture and history. However, in relation to that sphere every community develops its own clearly defined "gender ideology." Without it, the clothing itself does not have any particular meaning. It is only attributed to the attire by its socially defined function. There can be no doubt that it constitutes a visualisation of the body and of the personality. Subsequently, it has its social references both for the wearer and the onlooker. $^{2}$

Nowadays, transvestitism tends to be understood as a disorder of some sort, consisting in a predilection for cross-dressing, aimed at gaining satisfaction of either the emotional (dual-role transvestitism) or sexual (fetishist transvestitism) kind. In the Hebrew Bible, we seem to be able to find only a single law prohibiting thus defined transvestitism, which - as further research will show-may be the sole such precept not only in the Bible, but also in the entire ancient Near East. ${ }^{3}$ The dispute as to what it actually prohibits and for what reasons has been and is going on today. For even though the word "transvestitism" (Lat. trans "behind, beyond, on the other side"; vestitus - "clothing") is rather recent (it emerged as late as in 1910), the issues referred to therewith have been known for a long time. Nevertheless, the contemporary definition and understanding of these phenomena does not have to reflect the actual intentions of the biblical author. Now, in the context of modern culture - which sees not only changes in fashion and traditionally defined patterns of clothing "typical" for men and women, but also the emergence of new contexts for broadly conceived transvestism - the said interdiction in Deut 22:5 may be worth reconsidering, because sometimes a too literal reading of not always the best possible translation may lead to an overtly literal interpretation and thus result in a complete loss of the essence and spirit of the original text.

\footnotetext{
${ }^{2}$ John H. Walton, J. Harvey Walton, The Lost World of the Torah: Law as Covenant in Ancient Context (Downer Grove: IVP Academic 2019), 186.

3 P.J. Harland, "Menswear and Womenswear: A Study of Deuteronomy 22:5," Expository Times 110 (1998-1999): 73-6.
} 


\section{The Problem}

The law we want to analyse is of a rather peremptory character, and has the following wording:

lō'-jihjeh k- $k^{e} l \hat{\imath}$-geber 'al-'iššăh

$w^{e} l \bar{o}$-jilbbaš geber śimlat 'iššăh

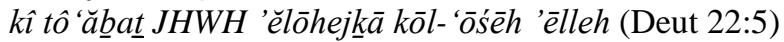

Here are some examples of its translations provided in various English versions of the Bible:

ASV (similarly: KJV, NKJ): A woman shall not wear that which pertaineth unto a man, neither shall a man put on a woman's garment; for whosoever doeth these things is an abomination unto Jehovah thy God.

BBE: It is not right for a woman to be dressed in man's clothing, or for a man to put on a woman's robe; whoever does such things is disgusting to the Lord your God.

ESV: A woman shall not wear a man's garment, nor shall a man put on a woman's cloak, for whoever does these things is an abomination to the LORD your God

LXE: The apparel of a man shall not be on a woman, neither shall a man put on a woman's dress; for every one that does these things is an abomination to the Lord thy God.

NAB: A woman shall not wear an article proper to a man, nor shall a man put on a woman's dress; for anyone who does such things is an abomination to the LORD, your God.

NAS (similarly: NET; NIB; NIV; NLT): A woman shall not wear man's clothing; nor shall a man put on a woman's clothing; for whoever does these things is an abomination to the LORD your God.

NJB: A woman must not dress like a man, nor a man like a woman; anyone who does this is detestable to Yahweh. 
NRS: A woman shall not wear a man's apparel, nor shall a man put on a woman's garment; for whoever does such things is abhorrent to the Lord your God.

And several more examples drawn from the commentaries:

J.R. Lundbom: An article of a man shall not be on a woman, and a man shall not wear a garment of a woman, for everyone who does these things is an abomination to Yahweh your God.

R.D. Nelson: A woman must not wear man's apparel, nor may a man put on a woman's garment; for whoever does these things is repugnant to Yahweh your God.

D.L. Christensen: Things pertaining to a man shall not be worn by a woman and a man shall not wear a woman's garment. For it is an abomination to YHWH your God.

It is not difficult to observe that the majority of the above translations renders the phrase $\underline{k}^{e} l \hat{\imath}$-geber as "man's clothing, man's garment, man's apparel," or in a more general sense: "A woman must not dress like a man, nor a man like a woman." Such an understanding of that expression would suggest that it is parallel to the second part of the verse, in which the phrase śimlat 'iššāh indubitably refers to "woman's garment; woman's robe; woman's; cloak; woman's dress; woman's clothing," for śimlat means: "outer clothing", "coat", "sheathing", i.e. most generally speaking "clothing, garment," but also a "cover," for instance, for a bed (Gen 9:23; Deut 22:17). As can be seen from the above instantiations, some translations see it fit to provide a wider meaning of the phrase $\underline{k}^{e} l \hat{\imath}$-geber, rendering it in a slightly different way as: that which pertaineth unto a man; an article proper to a man; an article of a man; things pertaining to a man.

The point is, however, that the phrase $\underline{k}^{e} l \hat{\imath}$-geber introduces two unknown elements. The first word $\left(\underline{k}^{e} l \hat{\imath}\right)$ has a wider, and thus less precise sense than merely that of a "garment," whereas the second one (geber), on the contrary, constitutes a very precise connotation of a male, placing emphasis upon the "masculinity," by which 
it reinforces the intended male-female contrast much more than it would have, had the lawgiver used for instance the juxtaposition

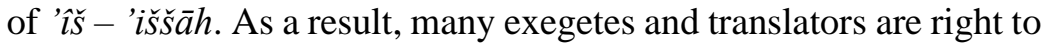
inquire about the precise meaning of the entire expression, as the lawgiver's choice of words seems to have been well thought out. The precept was probably introduced not as much to prohibit any switch in garment attributed within a specific culture to one of the sexes, as to prohibit transvestitism in specifically defined situations. ${ }^{4}$ The intention behind the law was, generally speaking, to prohibit transgressing certain boundaries. But precisely what limits are we talking about here? In what context should one be looking for references of that limitation? Thus, the question of the actual meaning of the phrase is accompanied by another: about the meaning of the above precise sense in the context of the quasimotivational formula ${ }^{5}$, evaluating the prohibited activities as tô 'ăbat $\mathrm{JHWH}^{6}$

We want to take a closer look at both these issues in this paper. First, we will analyse the literary context of the studied phrase, as well as its status quaestionis within the literary critical research.

\footnotetext{
${ }^{4}$ Nevertheless, when looking at the iconography, one cannot have any doubt as to whether in the biblical era there were standards regarding menswear and womenswear; cf. H. Weippert, "Kleidung," in Neues Bibel-Lexikon, vol. 2, eds. M. Görg, B. Lang (Zürich, Düsseldorf: Benziger 1995), 495-9, earlier by the same author "Kleidung," in Biblisches Reallexikon, ed. K. Galling (HAT Erste Reihe 1) (Tübingen: Mohr Siebeck 1977), 185-8.

${ }^{5}$ Gerhard von Rad, Teologia Starego Testamentu, Pol. transl. B. Widła (Warsaw: Pax 1986), 160, f.n. 21, refers to that justification as a "theological tautology," and thus not an actual justification. The formula points to something that can in no way be reconciled with the cult of JHWH. According to von Rad, the texts furnished with such a "tautological" motivation $(17: 1 ; 22: 5 ; 23: 19 ; 25: 16)$ may have even comprised a separate collection of liturgical precepts.

${ }^{6}$ A relatively complete review of the actual state of research, besides the abovecited commentaries (esp. by J.R. Lundbom, E. Otto), can also be found in a paper by N.S. Fox, "Gender Transformation and Transgression: Contextualizing the Prohibition of Cross-Dressing in Deuteronomy 22:5," in Mishneh Todah. Studies in Deuteronomy and Its Cultural Environment for J.H. Tigay, eds. N.S. Fox, D.A. Glatt-Gilad, M.J. Williams (Winona Lake: Eisenbrauns 2009), 49-71; C.L. Crouch, The Making of Israel: Cultural Diversity in the Southern Levant (Leiden, Boston: Brill 2014), 155-7, and in the article: Hilary Lipka, "The Prohibition of Cross-Dressing. What does Deuteronomy 22:5 Prohibit and Why?" [cited 10 June 2019]. Online: www.thetorah.com.
} 
Subsequently, we will go on to analyse the alternatives to the already cited possible exegetical and translatological interpretations of the Hebrew original. Lastly, we will explore the circumstances which according to exegetes may have led to the formulation of such a peremptory prohibition in Deut 22:5.

\section{Literary Context}

The pericope that introduces the analysed regulation does in itself constitute an actual small collection of laws. Hence, its delimitations vary. It proves difficult to unequivocally classify it according to its themes. The wider context displays traces of a larger whole (Deut 19:1-22:8), whose limits are marked by the theme of bloodguilt (19:10; 22:8: dāmîm). On a more focused look, we are dealing here with a set of family laws (Deut 22:13-21.22-29), various laws of social nature (Deut 22:1-4.6-8), and prohibitions pertaining to the mixing of crops (Deut 22:5.9-11). The direct context for the researched passage would, therefore, be either that of the pericope Deut 22:1-8, or that of Deut 22:1-12. In the first case, however, we are dealing with relatively loosely connected laws "hung upon" various instantiations of the commandment "thou shall not kill" (verses 6-7.8). Still, in the said mini-collection of laws, only the two final regulations pertain to that issue. ${ }^{7}$ For only these can be read as elaborations of the "thou shall not kill" theme. One involves the protection of a mother bird that has her fledglings (22:6-7), whereas the other concerns an unintentional bloodguilt, because of not fitting a parapet for the newly-built roof (22:8). The remaining laws have nothing to do with the theme of death and are rather loosely connected to one another (verses 1-3: the return of lost property; verse 4: the problem of a fallen cattle animal; verse 5: the prohibition of transvestitism). Nevertheless, exegetes have been able to indicate numerous minor linguistic connections that bind together the

\footnotetext{
${ }^{7}$ However, cf. S.A. Kaufman, "The Structure of the Deuteronomic Law," Maarav 12 (1978-1979): 136. The scholar suggests that verse 5, like the regulation in verses 6-7, concerns the theme of death (they share the notion of separation: man and woman; mother and her fledgelings). Still, the author rather assumes the interpretation than unequivocally proves it.
} 
respective laws of the collection. ${ }^{8}$ Thematically, however, Deut 22:5 is only associated with the laws presented in Deut 22:9-11, while taking into consideration the theme of "clothing," also in verse 12. For that reason, its current position within its context (i.e., between verses $1-4$, and verses $6-8$ ) seems rather puzzling. The structure of the prohibition formulated in verse 5 (third person singular used in a double formula) has counterparts in Deut 23:18; 24:16.

\section{Literary Criticism}

Gustav Hölscher ${ }^{9}$ wrote some time ago that "starting from chapter 22, any logical order of laws comes to an end." The scholar was also among the first to point out that Deut 22:1-4.6-7 constitutes a section of the so-called Ur-Deuteronomium, whereas Deut 22:5.9-12 mark a later addition. Carl Steuernage ${ }^{10}$ classified the entirety of Deut 22:1-23 as a material only secondarily included in the main body of the book. The review of the respective proposals demonstrates that these two opinions, alongside variants thereof, have been shared by other researchers. ${ }^{11}$ Considering the issues dealt with here, Deut 22:1-4 may be referred to the laws introduced in Exod 23:4-5, and treated as their elaboration or a completion of the preceding version of the Covenant Code. Meanwhile, Deut 22:9-11 is a clear-cut reference to Lev 19:19, and it is highly probable that it is predated by that passage in the Holiness Code, although-as others claim - it may have been the other way around, with the author of the Holiness Code having before him both the Covenant Code and the Deuteronomical Code. ${ }^{12}$ Deut 22:5, i.e., the regulation

\footnotetext{
${ }^{8}$ A. Rofé, "The Arrangement of the Laws in Deuteronomy," in Deuteronomy. Issues and Interpretation (London, New York: T\&T Clark 2002), 62, 72; J.R. Lundbom, Deuteronomy. A Commentary (Cambridge: Eerdmans 2013), 613. In the wider context (22:1-12), cf. E. Otto, Deuteronomium 12,1-23,15 (HThKAT) (Freiburg, Basel, Vienna: Herder 2016), 1676.

${ }^{9}$ G. Hölscher, "Komposition und Ursprung des Deuteronomiums," Zeitschrift für die alttestamentliche Wissenschaft 40 (1922): 209.

${ }^{10}$ C. Steuernagel, Das Deuteronomium übersetzt und erklärt (HK I 3/1) (Göttingen: Vandenhoeck\& Ruprecht ${ }^{2}$ 1923), 131-5.

${ }^{11}$ E. Otto, Deuteronomium 12,1-23,15, 1681-4.

12 So E. Otto, Deuteronomium 12,1-23,15, 1686.
} 
that we intend to analyse, is thematically linked to the matter of not mixing various crops, discussed in Deut 22:9-11. However, it must be pointed out that the two passages do not speak of quite the same issue. ${ }^{13}$ Verse 5 is associated with verse 12 through the theme of clothing. It seems valid to ask the question, why verse 5 was not directly placed within its proper context? Its location between Deut 22:1-4.6-8 seems of secondary nature, as observed by Hölscher, mentioned above. Does that mean, however, that verse 5 is a secondary addition to the entire collection? It is possible, although it cannot be ruled out either that the first part of it (verse $5 \mathrm{ab}$ ) was composed slightly earlier (cf. the already cited formulas in Deut 21:18 and 24:16), and was only later complemented with the motivational phrase in the section $5 \mathrm{c} .{ }^{14}$ But if indeed the entire law in Deut 22:5 constitutes a post-exilic Fortschreibung ${ }^{15}$, the interpretation thereof should focus most of all on the context of the entire Pentateuch.

\section{Wide Exegetical Opportunities}

The first and fundamental question is this: can we be sure that in verses $5 \mathrm{aA}$ and $5 \mathrm{aB}$, considering their parallelism, $\underline{k}^{e} l \hat{\imath}$-geber means the same thing as śimlat 'išš $\bar{a} h$, that is, respectively, "menswear" and "womenswear"? Even after a perfunctory glance at the meaning of the words $\underline{k}^{e} l \hat{\imath}$ and śimlat, the answer must be negative. Let us, therefore, take a closer look at the respective words that determine the proper sense of the entire expression.

13 According to Eugene H. Merrill, Deuteronomy (NAC 4) (Nashville: B\&H Publishing Group 1994), 297, Deut 22:5 is "a regulation that seems most intrusive in the overall passage."

${ }^{14}$ Such was the suggestion of, among others, Andre David H. Mayes, Deuteronomy (NCBC) (Grand Rapids: Eerdmans 1979; 21981), 307; Eduard Nielsen, Deuteronomium (HAT 1/6) (Tübingen: Mohr Siebeck 1995), 214.

15 So E. Otto, Deuteronomium 12,1-23,15, 1697-8, earlier also P.J. Harland, "Menswear," 73-6. 


\section{1. geber}

There can be no doubt that, besides the expression tô 'ăbat $J H W H$, it is the crucial word for the correct understanding of the meaning of this interdiction. In verse $5 \mathrm{aAB}$, it appears twice, being juxtaposed by the antonym principle with 'išš $\bar{a} h$ as the word referring to a woman. Hence, the meaning must be "male - female." But why did the lawgiver not go with the juxtaposition: ' $i ̂ s$ (in the sense: husband - wife; cf. Deut 22:13)? And yet, the application of the word geber seems rather well thought out. The noun is derived from the verbal stem $g b r$ - "be strong, dominate," 16 and - most importantly - does not have a feminine counterpart. ${ }^{17}$ In the case of the word ' $\hat{\imath} \hat{s}$, besides it having a feminine counterpart, it is also worth noting that it could also be used with a neutral meaning of: "human, people, person" (Cf. Exod 35:21). ${ }^{18}$ Similar is the case with other potential words that could be used in an attempt to connote "a man" ('ādām; 'énôs). In relation to all these words, the noun geber is unique, as it means solely an adult male (the exception being Job 3:3). Moreover, the word particularly underscores the "masculinity": courage, bravery, fortitude (Ps 127:5; Job 38:3). Accordingly, every man is an ' $\imath \hat{s}$, but not every man is a geber. The intensity of that noun is not as great as that of the word gibbôr, derived from the same verb stem; however, it is clear that it cannot be understood also as a mere casual connotation of "a man." 19 Sometimes, it is used as the synonym of the word $z \bar{a} k \bar{a} r$ - "man, male specimen" (Gen $1: 27 ; 5: 2 ; 6: 19 ; 7: 2)^{20}$, but the latter has

\footnotetext{
${ }^{16} \mathrm{Ges}^{18}$, vol. 1 (Berlin: Springer-Verlag 1987), 197: besides its general meaning, the basic Middle-Hebrew form has the fundamental meaning of: a male, and also: a rooster, a penis.

${ }^{17}$ The word $g^{e}$ bir $\hat{r}$ (cf. KBL, vol. 1, 164), although derived from the same stem, does not constitute a female counterpart of the word geber, for it has an entirely different semantic range. It emphasises rather the social standing than femininity; cf. H. Kosmala, "gabar," in TDOT, vol. 2 (Grand Rapids: Eerdmans 1977), 367-82, esp. 373; V.P. Hamilton, "gebîrâ," in NIDOTTE, vol. 1 (London: Paternoster Press 1997), 800-2.

${ }^{18}$ N.P. Bratsiotis, “'îš,” in TDOT, vol. 1 (Grand Rapids: Eerdmans 1977), 222-35.

${ }^{19}$ H. Kosmala, "gabar," in TDOT, vol. 2, 377-8.

${ }^{20}$ KBL, vol. 1, 259-60.
} 
an antonym in the noun $n^{e}$ gabāh (Gen 1:27; Jer 31:22). ${ }^{21}$ Hence, by choosing the word geber the lawgiver intended to connote a particular character of masculinity, and wanted to underscore it in its opposition to femininity. ${ }^{22}$

\section{2. $\underline{k}^{e} / \hat{\imath}$}

This noun possesses a very wide range of meanings. Firstly, it describes various types of containers, luggages, and devices. Next, it may refer to a tool, a weapon, and even an armour. Subsequently, it is used in descriptions of interior equipment, furniture, and various other home objects. Lastly, it may also mean jewellery and ornaments, as well as musical instruments. ${ }^{23}$ If we wanted to take its meaning even more generally, we could say that it serves to describe some personal property. Targum Pseudo-Jonathan suggests that verse 5aA should be understood as ritual men's attire (tefillim phylacteries, and tzit-tzit - ritual blue fringes). However, this interpretation was associated with a problem discussed much later, namely, whether women could wear ritual attire of that kind. Because of its connexion with the word geber, in the rabbinic exegesis of a later period proposals emerged to see Deut 22:5a as an interdiction of women wearing armour and weapons (Rabbi Eliezer ben Yaakov: Sifre Debarim $\S 226$; $b$. Nazir 59a). As we have noted, such a meaning of the word $\underline{k}^{e} l \hat{\imath}$ is not a rare phenomenon in the Hebrew Bible (Deut 1:41; Judg 18:11; 1 Sam 8:12; 2 Kgs 11:8; Jer 21:4). ${ }^{24}$ However, the translator of the Septuagint uses in this

21 About both these words, cf. J. Lemański, Księga Rodzaju rozdziaty 1-11 (NKB.ST I/1) (Częstochowa: Św. Paweł 2013), 169.

${ }^{22}$ On the precise meaning of all the above-mentioned words, and the various aspects they connote, cf. M. Zvi Brettler, "Gender in the Bible," in Jewish Study Bible, eds. A. Berlin, M. Zvi Brettler (New York: Oxford University Press 2014), 2177-84. Later also M. Zvi Brettler, "Happy is the man, who fills his quiver with them" (Ps 127:5): Construction of Masculinities in the Psalms," in Being a Man: Negotiating Ancient Constructs of Masculinity, ed. I. Zsolnay (Studies in the History of the Ancient Near East) (London: Routledge 2017), 198-203.

${ }^{23}$ K.M. Beyse, "kelî," in TDOT, vol. 7 (Grand Rapids: Eerdmans 1995), 169-75; DCH, vol. 4, 420-4. For Deut 22:5 in KBL, vol. 1, 456; DCH, vol. 4, 424 the suggested meaning is: "menswear."

${ }^{24}$ K.M. Beyse, "kelî," 172. 
instance the Greek word skeue, whose range of meaning is equally diverse as that of the Hebrew word $\underline{k}^{e} l \hat{\imath}$, that it renders. The Greek counterpart may refer to: clothing, attire, costume, wear, robe, as well as style, fashion, weaponry, whereas in the plural even to naval equipment. $^{25}$

In spite of the above, combined with the deliberately selected noun geber, the noun $\underline{k}^{e} l \hat{\imath}$ may mean a particular object belonging solely, or at least generally to a man: a weapon (Deut 1:41), although equally well some other, less "masculine" thing (Deut 23:25: a basket?). ${ }^{26}$

\section{3. śimlat}

Generally speaking, the word is used to denote something that covers a man or a thing (Gen 9:23; Deut 22:17). In the plural, it usually refers to clothing, including menswear (Gen 37:34; Exod 19:10; Josh 7:6). On such occasions, as in this one, it tends to be applied alongside the verb $l b \check{s}$ - "wear, put on." In the current case, the noun is qualified with the word 'išš $\bar{a} h$. Hence, we are dealing with female outer attire, and a prohibition for it to be worn by men (verse $5 \mathrm{aB}$ ).

${ }^{25}$ O, Jurewicz, ed., Stownik grecko-polski (Warsaw: Wydawnictwo Szkolne PWN 2001), 299. The meaning suggested for Deut 22:5 is: "outfit,” cf. J. Lust, E. Eynikel, K. Hauspie, A Greek - English Lexicon of the Septuagint, vol. 2 (Stuttgart: Deutsche Bibelgesellschaft 1996), 428. Later also H.A. Hoffner Jr., "Symbols for Masculinity and Femininity: Their Use in Ancient Near Eastern Pathetic Magic Rituals," Journal of Biblical Literature 85 (1966): 326-34, esp. 332-3.

${ }^{26}$ R.D. Nelson, Deuteronomy (OTL) (Louisville, London: John Knox Press 2002), 264 , even mentions that a proposal has been made to read the expression as "an artificial phallus." I was unable, however, to establish the source of this suggestion, while Nelson does not cite it. Nevertheless, the meaning should rather be general: "things pertaining to a man," so D.L. Christensen, Deuteronomy 21,10-34,12 (WBC 6B) (Nashville: Thomas Nelson Publishing 2002), 492. 


\section{4. tô‘ăbat JHWH}

The term tô' $\bar{e} \underline{b} \bar{a} h$ describes abhorrence, disgust. ${ }^{27}$ It occurs quite frequently in the Book of Deuteronomy ${ }^{28}$ It refers there to persons (Deut 23:8; 25:16), practices (Deut 24:4), and things (Deut 12:31; 14:3). It is predominantly the idols (Deut 7:25-26; 27:15; cf. Jer 16:18), and the people practicing idolatry (Deut 13:13-15; 17:2-4) that are considered tô 'éb̄a $h$ by JHWH. It is sometimes also applied with regard to divination (Deut 18:9-12). The oldest use of the word (Deut 32:16) ${ }^{29}$ refers to the cult of alien gods. Therefore, the term provides justification (motivation) of a predominantly cultic character. Later, however, also the interdiction of homosexuality is expressed in the same manner in Lev 18:22. Meanwhile, in the Deuteronomy, also the man who cheats with measures and weights turns out to be "repulsive" to JHWH (Deut 25:13-16; cf. Jer 6:15 = 8:12). Some foods are also considered to be abhorrent (Deut 14:3), so are imperfect sacrifices (Deut 17:1), and the analysed issue of cross-dressing (Deut 22:5).

In the collection of proverbs from the Paleo-Babylonian period, discovered on one of the school tablets from Nippur, the entire set ends with a similar word. For that reason William Hallo ${ }^{30}$ uses the phrase "punch-line" to describe it. The above text reads as follows:
"A judge who perverts justice,
a curse which falls on the righteous party
a (first-born) heir who drives the Younger (son)
out of the patrimony -
these are abomination of Ninurta."

Other proverbs from the collection end with evocations of other deities: "these are abomination of Utu, ... Suen, ... Marduk." In the

\footnotetext{
${ }^{27} \mathrm{KBL}$, vol. 2, 1568-70.

${ }^{28}$ S.R. Driver, A Critical and Exegetical Commentary on Deuteronomy (ICC) (Edinburg: T\&T Clark 1895), lxxxiii, f.n. 70; M. Weinfeld, Deuteronomy and Deuteronomic School (Oxford: Clarendon 1972), 323, f.n. 1.1a.

${ }^{29}$ M. Weinfeld, Deuteronomy, 323.

30 W.W. Hallo, "Biblical Abomination and Sumerian Taboos," The Jewish Quarterly Review 76 (1985-1986): 21-40, esp. 34, where the above citation can be found.
} 
Egyptian Instruction of Amenemope ${ }^{31}$, quoted by W. Hallo, some proverbs also conclude with the words: "it is abomination of god." Hence, according to the scholar, in all these cases, including Deut $22: 5 \mathrm{~b}$, we are dealing with the influences of the wisdom milieu, especially because we may also find similar expressions in the biblical Book of Proverbs (cf. Prov 6:16-19).

The current example (Deut 22:5) is considered by Richard Nelson $^{32}$ to be one of many instances, when the expression tô ' $a \underline{a} \underline{b} a t$ $J H W H$ echoes a more technical use of the entire phrase, its meaning extending further than solely the issue of ritual impurity (cf. Deut $14: 3 ; 17: 1 ; 18: 12 ; 23: 18-19 ; 24: 14)$. This concluding formula allows us to suppose that the interdiction pertains to matters more profound than mere cross-dressing. ${ }^{33}$

\section{Potential Sitz im Leben}

While exegetical discussion may lead to a relative consensus, namely, that we are dealing with an interdiction of transvestitism or of a reversal of typical roles attributed to either gender, the circumstances and scope of the regulation leave us with many questions. ${ }^{34}$ The very motivational formula suggests cultural influences of some sort (cf. Deut 7:25). However, as we have noted, verse $5 \mathrm{~b}$ may have been inserted later, which would in turn entail a number of various potential reasons for introducing such an interdiction.

\subsection{Participation in War}

The precursor of this interpretation, which-as already mentioned - would turn out to be quite popular in rabbinic exegesis, was Josephus Flavius, who wrote:

31 ANET $^{3}, 423$; chapters 10 and 13.

${ }^{32}$ Deuteronomy, 268.

${ }^{33}$ So quite correctly P.C. Craigie, The Book of Deuteronomy (NICOT) (Grand Rapids: Eerdmans 1976), 287.

34 A.D.H. Mayes, Deuteronomy, 307. N.S. Fox, "Gender," 49: "an odd duckunique to biblical law and unique in the corpus of ancient Near Eastern literature." 
Beware, above all in the battle, that no woman assume the accoutrements of a man nor a man the apparel of a woman (Ant. IV.43 [301])..$^{35}$

Thus, he took the expression $\underline{k}^{e} l \hat{l}$-geber to mean "the accoutrements (equipment) of a man," and the whole law as an element of regulations pertaining to the military attire required for war (cf. Sifre Debarim § 226). During that period, the Roman satirist Juvenal wrote in a similar vein:

Quem praestare potest mulier galeata pudorum, quae fugit a sexu? Uires amat (Sat. VI 252-253). ${ }^{36}$

What sort of bashfulness may be displayed by a woman wearing a helmet, who escapes her own sex? She loves power. ${ }^{37}$

Juvenal is speaking here of a woman who is fascinated by the contemporary military craft, i.e., typically manly matters. The inspiration for such an interpretation of the interdiction in Deut 22:5 has also been sought for in a passage from the Ugaritic Epic of Aqhat (KTU 1.19.iv.44-46). ${ }^{38}$ In it, a heroine named Paghat, willing to avenge the death of her brother, wears the outfit of a warrior (npṣ ǵzr) under her female garment (npṣ att). Her outer, woman's apparel helps her further to conceal a dagger and a sword. The disguise is to make her similar to the goddess Anat.

\footnotetext{
${ }^{35}$ Flavius Josephus, Jewish Antiquities, translated by H.St.J. Thackeray (The Loeb Classical Library) (London: Harvard University Press 1930; reprint 1961).

${ }^{36}$ Loeb Classical Library: loebclassics.com.

37 Translated after the Polish translation of the original text by the author.

${ }^{38}$ C.H. Gordon, "A Note on the Tenth Commandment," Journal of Bible and Religion 31 (1963): 208-9. The Polish translation of the text in: A. Tronina, "Eposy ugaryckie o Kerecie i Akhacie," in Scripturae Lumen. Biblia i jej oddziaływanie, vol. 1: Ewangelia o Królestwie, ed. A. Paciorek (Lublin: Wydawnictwo KUL 2009), 563-621, the passage referred to: 616.
} 
A context for Deut 22:5 parallel to those mentioned above has also been put forth by Harold Tolger Vedeler. ${ }^{39}$ In his view, the specificity of the expression $\underline{k}^{e} l \hat{\imath}$-geber indicates that in this legal precept we are not dealing with an interdiction of wearing male garments as such, but of women's access to the typically men's gear, which express masculine power and authority also in the religious sphere. $^{40}$

In fact, as noted above, the phrase $\underline{k}^{e} l \hat{\imath}$-geber may refer to a weapon (Deut 1:41), or other piece of equipment typically used by men (Gen 27:3: hunting gear); meanwhile, the noun geber may serve to accentuate "masculinity," which additionally corroborates the reading of the first section as "a weapon." However, neither context, nor formulation of the biblical passage in question point to such a narrowed-down interpretation of the law.

\subsection{Sexual Transgressions}

Cross-dressing may be aimed at seducing someone or at being identified with a certain group, with the intention of a prohibited sexual conduct. Only then it was believed to be interdicted according to rabbis (b. Nazir 59a; Rashi). ${ }^{41}$ For any other purposes, when celebrating the Purim festival for instance, it is permissible (Shulchan Aruch, OH 69b:8). Neither in the Hebrew Bible, nor in extra-biblical literature do we find any instances of transvestitism

\footnotetext{
${ }^{39}$ H.T. Vedeler, "Reconstructing Meaning in Deuteronomy 22:5: Gender, Society, and Transvestitism in Israel and the Ancient Near East," Journal of Biblical Literature 127 (2008): 459-76.

${ }^{40}$ H.T. Vedeler, "Reconstructing," 473. The interdiction is aimed at removing "all women from accessing a weapon or any other symbol of power not of men in general but of the most masculine and religious upright of men. The verse sets the $g b r$ clearly apart from women and the danger they represent." Intending to underscore the difference between geber and 'î̌s, Vedeler translates the entire phrase as meaning: "A woman shall not be associated with the instrument of a superior ..."

${ }^{41}$ A rich and possibly exhaustive (I did not have access to the work) range of references to rabbinic exegesis may be found in: T. Liebman, The Jewish Exegetical History of Deuteronomy 22:5: Required Gender Separation or Prohibited CrossDressing? (Master's Thesis; Montreal: Department of Jewish Studies, McGill University 2002).
} 
of the homosexual type, which is seen as the backdrop for this prohibition, among other scholars, by Calum M. Carmichael. ${ }^{42}$ He associates the practice of homosexuality with the regulations regarding war in Deut 20, and believes that it was intended to stop women willing to participate in battles from putting on armour (cf. Deut 3:19). However, none of the texts he analysed speaks directly of homosexuality. Neither is there any certainty that Deut 3:19 and 22:5 should be thematically linked.

Wilfred G. Lambert ${ }^{43}$ cites one of the proverbs dating back to the Middle Assyrian Empire, that appears to reflect the practice of transvestitism; however, it proves difficult to refer it to any particular context:

... An Amorite speaks [to] his wife, 'You be the man, [I] will be the woman. [Since ... I I became a man ... female ... male.

Lambert himself believes that kind of practice to have been condemned for the first time in our passage of Deut 22:5. Such conduct was certainly known and practiced in the classical world, in Greece, Asia Minor, and in the territories of Syria. ${ }^{44}$ However, their context was different and, most of all, it was in a period long afer that of the analysed interdiction in Deut 22:5. There are very few examples of such behaviour at the earlier stages. ${ }^{45}$ However, if the lawgiver had in mind any practices associated with

\footnotetext{
42 C.M. Carmichael, The Law of Deuteronomy (Ithaca: Cornell University Press 1974), 147.

${ }^{43}$ W.G. Lambert, Babylonian Wisdom Literature (Oxford: Clarendon 1960), 126, 226, 230.

${ }^{44}$ S.R. Driver, Deuteronomy, 250; Th.H. Gaster, Myth, Legend, and Custom in the Old Testament (New York: Harper \& Row 1969), 316-7; H. Licht, Sexual Life in Ancient Greece, transl. J.H. Freese (London: Constable 1994; Ger. org. 1931), 124-5, 500; M.E. Doerfler, "Coming Apart at the Seams: Cross-dressing Masculinity, and the Social Body in Late Antiquity," in Dressing Judeans and Christians in Antiquity, eds. A. Batten, C. Daniel-Hughes, K. Upson-Saia (Burlington: VT: Ashgate 2014), 37-54.

${ }^{45}$ N.S. Fox, "Gender," 49-71.
} 
homosexuality ${ }^{46}$, these had been abolished by a general prohibition thereof in Israel (Lev 18:22; 20:13).$^{47}$ Even were we to assume that he returns to the issue due to the prohibition of mixing crops (in this case - attire typical for a given gender), we must bear in mind that the Old Testament only knows male homosexuality, providing no indication as to its female variety. ${ }^{48}$ Thus, the first part of the analysed interdiction (verse $5 \mathrm{aA}$ ) proves to be an exception and one difficult to justify.

\subsection{Idolatry and Magic}

The prohibition of certain ritual behaviour associated with alien cultures is a frequent motif referred to by the commentators. ${ }^{49}$ In fact, it was already Maimonides who associated the interdiction with idolatry (The Guide for the Perplexed 3:37). Researchers have emphasised on numerous occasions that such practices where known to the Mesopotamian cult of Inanna/Ishtar, or the Canaanite cult of Astarte..$^{50}$ The goddess had certain androgynous qualities, and

\footnotetext{
${ }^{46}$ Such is the suggestion of, inter alios, E. Otto, Deuteronomium 12,1-23,15, 1698, who points to the opinion expressed by J. Milgrom.

${ }^{47}$ W.W. Hallo, "Biblical Abomination," 37; H.T. Vedeler, "Reconstructing," 468.

${ }^{48}$ On the issue of homosexuality in the Hebrew Bible, cf. I. and J. Slawik, "Homoseksualizm problemem Kościoła?," Rocznik Teologiczny 52 (2010): 9-69; J. Lemański, Księga Rodzaju rozdziały 11,27-36,43 (NKB.ST I/1) (Częstochowa: Św. Paweł 2014), 393-404.

49 So, for instance Georg Braulik, Deuteronomium II 16,18-34,12 (NEB) (Würzburg: Echter Verlag 1992), 161-2; Jeffrey H. Tigay, Deuteronomy (JPS Torah Commentary) (Philadelphia: Jewish Publication Society 1996), 200; Ciril S. Rodd, Glimpses of a Strange Land. Studies in Old Testament Ethics (Edinburg: T\&T Clark 2001), 11; Simone Paganini, Deuteronomium (I libri Biblici. Primo Testamento) (Milan: Paoline 2011), 329. From among the earlier generations of exegetes, one could indicate G. von Rad, Deuteronomio, It. transl. A dal Bianco (Brescia: Paidea Editrice 1979; Ger. org. 1964), 157; S. Łach, Księga Powtórzonego Prawa (PŚST II-3) (Poznań, Warsaw: Pallottinum 1971), 221; A. Penna, Deuteronomio (Turin, Rome: Manetti 1976), 202; A.D.H. Mayes, Deuteronomy, 307.

${ }^{50}$ W.H.Ph. Römer, "Randbemerkungen zur Travestie von Deut. 22.5," in Travestie in the World of the Old Testament (Studia Semitica Neerlandica 16), eds. M. Heerm van Voss et al. (Assen: Van Gorcum 1974), 217-22; W.W. Hallo, "Biblical Abomination," 21-40.
} 
hence she represented something unknown to the biblical anthropology - the third gender (androgyny - hermaphroditism)..$^{51}$ Similar characteristics may also have been shared by the Syriac goddess Anat. It is suggested by an extant passage of a text in Egyptian. ${ }^{52}$ The latter has been compared to the Ugaritic Baal and Anat cycle. In the quoted fragment, the deity Re/El addresses the goddess in the following manner:

"What has happened to you, Anat, o victorious woman, who is like a man, dressed like a man, yet girded like a woman?"

The qualities of the goddess Inanna/Isthar/Anat and the specific nature of their cult survived to the later period in the cult of the goddess Atargatis. ${ }^{53}$ Thus, it may have been known in the post-exilic Judea (cf. 2 Macc 12:26).

In the Mesopotamian mythology and cult, gods and goddesses often switched their gender roles. In a prayer dating back to the NeoBabylonian period, Isthar was addressed as "a lioness," only to be called "a fierce lion" a moment later. ${ }^{54}$ There also is a Hittite basrelief with a prayer of supplication in suffering, in which the orant speaks to the god of sun, with the following words:

[Thou], my god, [(art) father and mother].$^{55}$

51 C.L. Crouch, The Making, 156. Later also B. Groneberg, "Die sumerischakkadische Inanna/Ištar: Hermaphroditas?," Die Welt des Orients 17 (1986): 25-46; R. Harris, "Inanna-Istar as Paradox and a Coincidence of Opposites," History of Religion 30 (1991): 261-78 = in Gender and Ageing in Mesopotamia: The Gilgamesh Epic and Other Ancient Literature, ed. R. Harris (Norman: University of Oklahoma Press 2000), 158-71; L.M. Pryke, Ishtar: Gods and Heroes of Ancient World (London, New York: Routledge 2017). In Polish, cf. the entry "Inana/Isztar," in Stownik mitologii Mezopotamii, eds. J. Black, A. Green (Katowice: Książnica 1998), 86-9.

52 E. Otto, Deuteronomium 12,1-23,15, 1698, cites it following W. Helck, Betrachtungen zur großen Göttin und der ihn verbundenen Gottheiten (Religion und Kultur der alten Mittelmeerwelt in Parallelforschungen 2) (Munich, Vienna: Oldenbourg 1971), 153.

${ }^{53}$ H.J.W. Drijvers, "Atargatis," in Dictionary of Deities and Demons in the Bible, eds. K. van der Toorn et al. (Leiden, Boston, Cologne: Brill 1999), 114-6.

${ }^{54} \mathrm{ANET}^{3}, 384$, lines 31, 51.

$55 \mathrm{ANET}^{3}, 401$. 
This "shift in gender" of the deity may have led to a cult in which the believers attempted to adjust themselves to the notion of the god or goddess they worshipped. So it was particularly in the case of a goddess. ${ }^{56}$ The famous text attributed to Lucian of Samosata (De Dea Syria $)^{57}$ provides an account of practices associated with the religion celebrated in Hierapolis (former Mabog), a centre of the cult of the goddess Rhea. The priest Gallus, willing to sacrifice himself entirely to the revered goddess, performed the act of self-castration, abandoned masculine lifestyle, and started to wear women's clothes. However, there is no evidence that such a cult of this SumeroBabylonian goddess was at any time practiced in Israel, and even less that customs similar to those described by Lucian were adopted there. Even if we assume that such practices were known to direct neighbours of the Israelis, in this case we continue to lack the evidence that the Israelis did in fact participate in those. Furthermore, the Deuteronomist criticises any form of idolatry (Deut $12: 29-31 ; 13: 13-19 ; 17: 2-7$ ), so there was no need to specify one of those in such a manner.

Meanwhile, Harry A. Hoffner ${ }^{58}$ suggests that we are dealing with a prohibition of a particular type of magical behaviour, known in Canaan and in the Hittite religion. The items used in practices of that sort would symbolise masculinity and heroism (bow), or femininity and fertility (hairpins, mirrors). The general idea was to dress up in order to symbolically emphasise masculinity or femininity, which—according to Hoffner ${ }^{59}$ — was aimed "to maintain, restore

${ }^{56}$ W. Roscoe, "Priest of the Goddess: Gender Transgression in Ancient Religion," History of Religion 35 (1996): 213-7. Also on this topic: N.S. Fox, "Gender," 523; H.T. Vedeler, "Reconstructing," 464-9. This custom was known not only in Mesopotamia, it was also practiced in northern Canaan, Transjordan, Philistia, and even in the surroundings of Beersheba, in the valley of Azal; cf. R. Kletter, "Pots and Polities: Material Remains of Late Iron Age Judah in Relation to Its Political Border," Bulletin of the American Schools of Oriental Research 34 (1999): 19-54, 381-5; N.S. Fox, "Gender," 57-8, 61-2.

${ }^{57}$ H.W. Attridge, R.A. Oden, The Syrian Goddess (De Dea Syria). Attributed to Lucian (Society of Biblical Literature. Texts and Translations 9) (Missoula: Scholars 1976), 23, 37, 39, 55.

58 "Symbols," 326-34.

59 Ibid., 334. 
or eradicate the sexual potency of oneself or one's enemy." Israel also knew curses and maledictions against one's enemies. Perhaps the verbal formulae were augmented by special rituals and disguises. Still, it is not mentioned directly in Deut 22:5, and the interdiction is so general that we should be weary when assessing the validity of any such suggestions. ${ }^{60}$

\subsection{Order Defined by the Act of Creation}

This aspect was particularly stressed by Cornelius Houtman. ${ }^{61}$ However, it was already Philo of Alexandria who wrote about it in a similar tenor in his times (20 B.C.-A.D. 40/50?):

IV. (18) But such great anxiety and energy is displayed by the law in attaining the object of training and exercising the soul so as to fill it with courage, that it has even descended to particulars in the matter of raiment, enjoining what men ought to wear, and prohibiting with all its might a man from wearing the garments of a woman, in order that no trace of shadow of the female may be attached to the male part of mankind, to its discredit; for the law, being at all times in perfect consistency and accordance with nature, desires to establish laws which shall be akin to and in perfect harmony with one another from beginning to end, even in those minute points which, by reason of their insignificance, appear to be beneath the notice of ordinary legislators. (19) For as it perceived that the figures of men and women, looking at them as if they had been sculptured or painted forms, were very dissimilar, and, moreover, that the same kind of life was not assigned to both the sexes (for to the woman is assigned a domestic life, while a political one is more suited to the man), so also in respect of other matters which were not actually the works of nature, but still were in strict accordance with nature, it judged it expedient to deliver injunctions which were the result of sound sense and wisdom. And these related to the mode of living, and to

\footnotetext{
${ }^{60}$ N.S. Fox, “Gender,” 68-9; E. Otto, Deuteronomium 12,1-23,15, 1697.

${ }^{61}$ C. Houtman, "Another Look at Forbidden Mixtures," Vetus Testamentum 34 (1984): 226-8.
} 
apparel, and to other things of that kind; (20) for it thought it desirable that he who as truly a man should show himself a man in these particulars also, and especially in the matter of dress, since, as he wears that both day and night, he ought to take care that there is no indication in it of any want of manly courage. (21) And, in the same manner, having also equipped the woman in the ornaments suited to her, the law prohibits her from assuming the dress of a man, keeping at a distance men-women just as much as it does women-men; for the lawgiver was well aware that when only one single thing in the proper economy of the house was removed, nothing else would remain in the same position as it ought and as it was in before. (Peri aretōn 18-21). ${ }^{62}$

Here, Philo undoubtedly refers to the Graeco-Roman culture, dominant in his times, in which both sexes had their specific social roles attributed to them. He invokes the Greek notion of andreia "manliness," and it is on the latter that he founds his entire understanding of the interdiction in Deut 22:5, a passage he markedly refers to. The ultimate point of reference in his theory is the God-created order of nature. In recent years, also because of the dominant position of the post-exilic dating of the text, such a context for the Deut 22:5 has gained the greatest number of adherents. ${ }^{63}$

Deut 22:5 fits in with the idea that one ought to live in harmony with the order established in the act of creation, keeping separate what had been naturally separated and differentiated (various animals, grains, materials, cloths typical for both sexes, and the difference of kind: human - animals; cf. Lev 19:19; Deut 22:5; 27:21). The Book of Deuteronomy in general retains such an understanding of the order of creation, and through its various precepts expresses the intention to keep intact this natural distinction

62 The Works of Philo: Complete and Unabridged, translated by Charles Duke Yonge 1854-1857, on-line: http://www.earlyjewishwritings.com/text/philo/ book31.html.

${ }^{63}$ Cf. discussions and authors cited in: J. Goldingay, Old Testament Theology, vol. 3: Israel's Life (Dovners Grove: IPV Academic 2009), 613. 
bestowed upon the world in the act of creation (cf. Gen 1:4.67.14.18). ${ }^{64}$

Considering the above, Tikva Frymer-Kensky ${ }^{65}$ sees the fundamental motivation for introducing the interdiction in the fact that even a mere blurring of the symbolic boundaries enabling one to differentiate between the sexes constitutes a breach of the natural division to men and women. The division of human nature between the two sexes, as described in Gen 1-2, has been pointed out as the basic justification of the condemnation also by Gordon J. Wenham ${ }^{66}$ and Peter J. Harland. ${ }^{67}$ Particularly the latter scholar assumes the post-exilic origin of the interdiction in Deut 22:5. For that reason, he considers its dependence on the fundamental anthropological traits indicated in Gen 1-2 to be obvious. He indicates the keeping of the order of creation described in Gen 1 as the condition determining Israel's existence as "the holy people."68

In the broader sense, the considerations pertain to abuse or obscuring natural and social boundaries, which - according to the laws in Lev 19:19 (about not mixing different kinds; cf. Deut 22:9-11) — may be the cause of incurring ritual impurity. Bearing in mind the probable post-exilic context of this prohibition (Deut 22:5), it is the environment of the entire Pentateuch, as already indicated, that should be taken into consideration in the interpretation thereof. Consequently, one should assume that the lawgiver intends in this case to protect both the generally conceived principle of not mixing kinds, and the - typical for biblical anthropology-division of mankind to two sexes (Gen 1:26-27; 2:7-25). In the world of the bible, it is the attire that decides about the identity of a given person

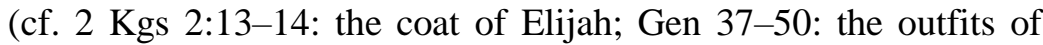

\footnotetext{
${ }^{64}$ A.D.H. Mayes, Deuteronomy, 306; P.D. Miller, Deuteronomy (Louisville: John Knox 1990), 162; M.E. Biddle, Deuteronomy (Macon: Smith \& Helwys 2003), 347. 65 T. Frymer-Kensky, "Law and Philosophy: The Case of Sex in the Bible," Semeia 45 (1989): 96-7.

66 G.J. Wenham, "The Old Testament Attitude to Homosexuality," Expository Times 102 (1990-1991): 259-363.

${ }^{67}$ P.J. Harland, "Menswear and Womenswear," 76.

${ }^{68}$ Ibid., 75-6.
} 
Joseph) ${ }^{69}$ These should therefore be worn according to the socially accepted principles and one's position in a given community.

Nili Sacher Fox ${ }^{70}$, whose work has already been mentioned, believes the motivation behind the introduction of the interdiction to have been the very structure of a patriarchal community, leading a predominantly farmers' lives, and residing in small settlements. The basic model for that type of communities was the division between the two sexes, men and women. However, would the lawgiver have required such a marked expression as $\underline{k}^{e} \hat{\imath}$-geber $?^{71}$ The patriarchal trope seems valid in this context, but it rather means that the regulation is to protect particularly all that is masculine within the community of Israel. Hence, women should not appropriate typical male equipment ( $\left.\underline{k}^{e} l \hat{\imath}-g e \underline{b} e r\right)$, whereas men must not in any way dress as women (effemination).

\section{Conclusion}

The above-analysed law, Deut 22, is of peremptory character. It comprises a pair of parallel interdictions and a quasi-motivational formula (tô $\breve{a} \underline{b} a t J H W H$ ), which classifies it within the context of Deuteronomy as one of the norms protecting the principles of appropriate practice of the cult, or proper conduct allowing one to participate therein. However, if either the entire law or solely the motivational formula are of a post-exilic origin, as the majority of researchers tends to believe, the number of interpretative options plummets. We are ignorant of the initial circumstances behind the prohibition in the section Deut 22:5ab. We do not even known whether we should be on a search for any primordial Sitz in Leben of the prohibition. If so, there may have been some unorthodox cultic behaviours within Jahwism, or downright alien cults performed in Israel. It cannot be ruled out, however, that the lawgiver had originally intended something completely different. With regard to that we are bound to remain within the realm of speculation. If, however, the entire regulation, and not merely its final section (5c),

${ }^{69}$ E. Otto, Deuteronomium 12,1-23,15, 1698.

70 N.S. Fox, "Gender," 49-71.

${ }^{71}$ For the discussion of the matter, see esp.: H.T. Vedeler, "Reconstructing," 471-3. 
was formulated after the exile, then both the interdiction and the quasi-motivational formula accompanying it may constitute a mere reference to the context, in this case of the entire Pentateuch. Hence, what comes to the fore here is the biblical anthropology with itsclearly defined-structure of human divided into two sexes, and immediately after that the order of creation, understood as differentiation to species and genera among the creation (Gen 1-2; Lev 19:19; Deut 22:9-11). Such a reading of the law is corroborated by its "erroneous" location in the context. Even though it is thematically related to Deut 22:9-11/12, it was placed between Deut 22:1-4.6-8. Its current position within the context may therefore be understood as a result of a subsequent, deliberate glossing. Still, what was the function of such a positioning? Perhaps it was meant to accentuate one of the aspects associated with the theme of "preserving life" (cf. verses 6-8)? ${ }^{72}$ In that sense, the loss of gender identity could lead to the inhibition of procreational activity (cf. Gen $1: 28 ; 5: 1-3 ; 9: 1.7) .{ }^{73}$ On the other hand, I believe such a canonical way of interpreting this regulation not to exhaust its complete, and perhaps even its fundamental meaning. The deliberate wording (particularly the choice of the phrase $\underline{k}^{e} l \hat{\imath}$-geber) leads us to believe that the lawgiver intended to strongly emphasise "masculinity" (the word geber), and all that is specifically associated with such "masculinity" (the word $\underline{k}^{e} l \hat{\imath}$ ). It may refer to broadly conceived attire, but also to weapons and other pieces of "manly" equipment. Conversely, the expression śimlat 'iššăh, connoting the outer garment of a women also pertains to a general prohibition of cross-dressing as women. Thus, both formulae are intended to "protect the specific character of masculinity," to interdict the transgression of boundaries within this sphere, binding for a patriarchal society, and not merely to prohibit the practice of crossdressing as such. In other words, women should not reach for what is uniquely masculine (masculinisation), nor-even more

\footnotetext{
72 However, through the word "clothing" (śimlat) verse 5 is linguistically and thematically linked only to verses 3 (léśimlātô) and 12 (kěsûteke $\bar{a})$.

73 The community is accused of the abandonment of that duty, resulting from the practice of divorce, also by the prophet Malachi (cf. Mal 2:10-16, esp. 15), who treats such conduct as a breach of the covenant with God.
} 
decidedly — should men effeminate themselves by wearing women's garments.

\section{Bibliography}

Ancient Near Eastern Texts Relating to the Old Testament, ed. J.B. Pritchard (Princeton: University Press 3 1969) (= ANET3).

Attridge H.W., Oden R.A., The Syrian Goddess (De Dea Syria). Attributed to Lucian (Society of Biblical Literature. Texts and Translations 9) (Missoula: Scholars 1976).

Beyse K.M., "kelî", in TDOT, vol. 7 (Grand Rapids: Eerdmans 1995), $169-75$.

Biddle M.E., Deuteronomy (Macon: Smith\&Helwys 2003).

Bratsioti N.P., "'îš", in Theological Dictionary of the Old Testament, vol. 1 (Grand Rapids: Eerdmans 1977), 222-235 (= TDOT).

Braulik G., Deuteronomium II 16,18-34,12 (NEB) (Würzburg: Echter Verlag 1992).

Brettler M. Zvi, „Gender in the Bible”, in Jewish Study Bible, eds. A. Berlin, M. Zvi Brettler (New York: Oxford University Press 2014), 2177-84.

Brettler M. Zvi, "Happy is the man, who fills his quiver with them" (Ps 127,5): Construction of Masculinities in the Psalms", in Being a Man: Negotiating Ancient Constructs of Masculinity, ed. I. Zsolnay (Studies in the History of the Ancient Near East) (London: Routledge 2017) 198-203.

Carmichael C.M., The Law of Deuteronomy (Ithaca: Cornell University Press 1974).

Christensen D.L., Deuteronomy 21,10-34,12 (WBC 6B) (Nashville: Thomas Nelson Publishing 2002).

Craigie P.C., The Book of Deuteronomy (NICOT) (Grand Rapids: Eerdmans 1976).

Crouch C.L., The Making of Israel: Cultural Diversity in the Southern Levant (Leiden, Boston: Brill 2014).

The Dictionary of Classical Hebrew, vol. 1-8, ed. D.J.A. Clines (Sheffield: Academic Press 1993- 2011) = DCH.

Doerfler M.E., "Coming Apart at the Seams: Cross-dressing Masculinity, and the Social Body in Late Antiquity", in Dressing Judeans and Christians in Antiquity, eds. A. Batten, C. Daniel-Hughes, K. UpsonSaia (Burlington: VT: Ashgate 2014), 37-54. 
Drijvers H.J.W., "Atargatis", in Dictionary of Deities and Demons in the Bible, ed. K. van der Toorn et al. (Leiden, Boston, Köln: Brill 1999), 114-6.

Driver S.R., A Critical and Exegetical Commentary on Deuteronomy (ICC) (Edinburg: T\&T Clark 1895).

Flavius Josephus, Jewish Antiquities, translated by H. St. J. Thackeray (The Loeb Classical Library) (London: Harvard University Press 1930; reprint 1961).

Fox N.S., "Gender Transformation and Transgression: Contextualizing the Prohibition of Cross-Dressing in Deuteronomy 22:5", in Mishneh Todah. Studies in Deuteronomy and Its Cultural Environment. Fs. J. H. Tigay, eds. N.S. Fox, D.A. Glatt-Gilad, M.J. Williams (Winona Lake: Eisenbrauns 2009), 49-71.

Frymer-Kensky T., "Law and Philosophy: The Case of Sex in the Bible", Semeia 45 (1989): 89-102.

Gaster Th.H., Myth, Legend, and Custom in the Old Testament (New York: Harper \& Row 1969).

Gesenius Hebräisches und aramäisches Handwörterbuch über das Alte Testament, eds. R. Meyer, H. Donner, vol. 1-7 (Berlin: Springer Verlag 1987-2012) (= Ges18).

Goldingay J., Old Testament Theology. Vol. 3: Israel's Life (Dovners Grove: IPV Academic 2009).

Gordon C.H., "A Note on the Tenth Commandment", Journal of Bible and Religion 31 (1963): 208-9.

A Greek - English Lexicon of the Septuagint, vol. 1-2, red. J. Lust, E. Eynikel, K. Hauspie, (Stuttgart: Deutsche Bibelgesellschaft 1996).

Groneberg B., "Die sumerisch-akkadische Inanna/Ištar: Hermaphroditas?", Die Welt des Orients 17 (1986): 25-46.

Hallo W.W., „Biblical Abomination and Sumerian Taboos”, The Jewish Quarterly Review 76 (1985-1986): 21-40.

Hamilton V.P., "gebîrâ", in NIDOTTE, vol. 1 (London: Paternoster Press 1997), 800-2.

Harland P. J., "Menswear and Womenswear: A Study of Deuteronomy 22:5", Expository Times 110 (1998-1999): 73-6.

Harris R., "Inanna-Istar as Paradox and a Coincidence of Opposites" History of Religion 30 (1991) 261-78 = in Gender and Aging in Mesopotamia: The Gilgamesh Epic and Other Ancient Literature, ed. R. Harris (Norman: University of Oklahoma Press 2000) 158-71.

Helck W., Betrachtungen zur großen Göttin und der ihn verbundenen Gottheiten (Religion und Kultur der alten Mittelmeerwelt in Parallelforschungen 2) (München, Wien: Oldenbourg 1971). 
Hölscher G., "Komposition und Ursprung des Deuteronomiums", Zeitschrift für die alttestamentliche Wissenschaft 40 (1922): 161-225. Hoffner H.A.Jr., "Symbols for Masculinity and Femininity: Their Use in Ancient Near Eastern Pathetic Magic Rituals", Journal of Biblical Literature 85 (1966): 326-34.

Houtman C., "Another Look at Forbidden Mixtures", Vetus Testamentum 34 (1984): 226-8.

Kaufman S.A., "The Structure of the Deuteronomic Law", Maarav 12 (1978-1979): 105-58.

Kletter R., "Pots and Polities: Material Remains of Late Iron Age Judah in Relation to Its Political Border", Bulletin of the American Schools of Oriental Research 34 (1999): 19-54, 381-5.

Koehler L., Baumgartner W., Hebräisches und Aramäisches Lexikon zum Alten Testament, vol. I-II (Leiden, New York, Köln: Brill 1995) = KBL.

Kosmala H., "gabar", in Theological Dictionary of the Old Testament, vol. 2 (Grand Rapids: Eerdmans 1977) 367-82.

Lambert W.G., Babylonian Wisdom Literature (Oxford: Clarendon 1960). Lemański J., Księga Rodzaju rozdziały 1-11 (NKB.ST I/1) (Częstochowa: Św. Paweł 2013).

Lemański J., Księga Rodzaju rozdziały 11,27-36,43 (NKB.ST I/1) (Częstochowa: Św. Paweł 2014).

Licht H., Sexual Life in Ancient Greece, transl. J.H. Freese (London: Constable 1994; German original from 1931).

Liebman T., The Jewish Exegetical History of Deuteronomy 22:5: Required Gender Separation or Prohibited Cross-Dressing? (Master's Thesis; Montreal: Department of Jewish Studies, McGill University 2002).

Lipka H., "The Prohibition of Cross-Dressing. What does Deuteronomy 22: 5 Prohibit and Why?," thetorach.com (access 10.06.2019).

Loeb Classical Library, loebclassics.com.

Lundbom J.R., Deuteronomy. A Commentary (Cambridge: Eerdmans 2013).

Łach S., Księga Powtórzonego Prawa (PŚST II-3) (Poznań, Warszawa: Pallottinum 1971).

Mayes A.D.H., Deuteronomy (NCBC) (Grand Rapids: Eerdmans 1979; $\left.{ }^{2} 1981\right)$.

Merrill E.H., Deuteronomy (NAC 4) (Nashville: B\&H Publishing Group 1994).

Miller P.D., Deuteronomy (Louisville: John Knox 1990) 162. 
Nelson R.D., Deuteronomy (OTL) (Louisville, London: John Knox Press 2002).

Nielsen E., Deuteronomium (HAT 1/6) (Tübingen: Mohr Siebeck 1995).

Otto E., Deuteronomium 12,1-23,15 (HThKAT) (Freiburg, Basel, Wien: Herder 2016).

Paganini S., Deuteronomium (I libri Biblici. Primo Testamento) (Milano: Paoline 2011).

Penna A., Deuteronomio (Torino, Roma: Manetti 1976).

The Works of Philo: Complete and Unabridged, translated by Charles

Duke Yonge 1854-1857, online version: earlyjewishwritings.com/ philo.html.

Pryke L.M., Ishtar: Gods and Heroes of Ancient World (London, New York: Routledge 2017).

Rad G. von, Deuteronomio, transl. A dal Bianco (Brescia: Paidea Editrice 1979; German original from 1964).

Rad G. von, Teologia Starego Testamentu, transl. B. Widła (Warszawa: Pax 1986).

Rodd C.S., Glimpses of a Strange Land. Studies in Old Testament Ethics (Edinburg: T\&T Clark 2001).

Römer W.H.Ph., "Randbemerkungen zur Travestie von Deut. 22.5", in Travestie in the World of the Old Testament (Studia Semitica Neerlandica 16), red. M. Heerm van Voss i inni (Assen: Van Gorcum 1974), 217-22.

Rofé A., "The Arrangement of the Laws in Deuteronomy", in Deuteronomy. Issues and Interpretation (London, New York: T\&T Clark 2002) 55-77.

Roscoe W., "Priest of the Goddess: Gender Transgression in Ancient Religion”, History of Religion 35 (1996): 213-7.

Slawik J., Slawik I., „Homoseksualizm problemem Kościoła?”, Rocznik Teologiczny 52 (2010): 9-69.

Stownik grecko-polski, ed. O. Jurewicz (Warszawa: Wydawnictwo Szkolne PWN 2001).

Słownik mitologii Mezopotamii, eds. J. Black, A. Green (Katowice: Księżnica 1998).

Steuernagel C., Das Deuteronomium übersetzt und erklärt (HK I 3/1) (Göttingen: Vandenhoeck\& Ruprecht ${ }^{2} 1923$ ).

Tigay J.H., Deuteronomy (JPS Torah Commentary) (Philadelphia: Jewish Publication Society 1996).

Tronina A., "Eposy ugaryckie o Kerecie i Akhacie", in Scripturae Lumen. Biblia $i$ jej oddziaływanie, vol. 1: Ewangelia o Królestwie, ed. A. Paciorek (Lublin: Wydawnictwo KUL 2009), 563-621. 
Vedeler H.T., "Reconstructing Meaning in Deuteronomy 22:5: Gender, Society, and Transvestitism in Israel and the Ancient Near East", Journal of Biblical Literature 127 (2008): 459-76.

Walton J.H., The Lost World of the Torah: Law as Covenant in Ancient Context (Downer Grove: IVP Academic 2019).

Weinfeld M., Deuteronomy and Deuteronomic School (Oxford: Clarendon 1972).

Weippert H., "Kleidung", in Biblische Reallexikon, ed. K. Galling (HAT Erste Reihe 1) (Tübingen: Mohr Siebeck 1977), 185-8.

Weippert H., "Kleidung", in Neues Bibel-Lexikon, vol. 2, eds. M. Görg, B. Lang (Zürich, Düsseldorf: Benziger 1995) 495-499.

Wenham G.J., "The Old Testament Attitude to Homosexuality", Expository Times 102 (1990-1991): 259-363. 